\title{
Cointegration with Regime Shift between Gold and Financial Variables
}

\author{
Takashi Miyazaki $^{1} \&$ Shigeyuki Hamori ${ }^{2}$ \\ ${ }^{1}$ Research Fellow, Graduate School of Economics, Kobe University, Kobe, Japan \\ ${ }^{2}$ Faculty of Economics, Kobe University, Kobe, Japan \\ Correspondence: Shigeyuki Hamori, Faculty of Economics, Kobe University, 2-1, Rokkodai, Nada-Ku, Kobe \\ 657-8501, Japan. E-mail: hamori@econ.kobe-u.ac.jp
}

Received: August 1, 2014

Accepted: August 26, $2014 \quad$ Online Published: September 5, 2014

doi:10.5430/ijfr.v5n4p90

URL: http://dx.doi.org/10.5430/ijfr.v5n4p90

\begin{abstract}
This paper investigates the long-run relationship between gold and three main financial variables based on daily data from January 1990 to May 2013. By using the Gregory-Hansen cointegration test, we show that there exists a cointegrating relation with regime shift between gold and the three financial variables, namely the short-term interest rate, value of US dollar, and stock index. Furthermore, taking into account the regime shift, we estimate the cointegrating vector by employing the dynamic ordinary least squares estimation and find that the coefficients of most of the financial variables have grown in terms of absolute value in later years. This finding implies that gold has begun to be regarded as an important financial asset for making effective investments.
\end{abstract}

Keywords: financialization of commodities, gold, financial variables, cointegration with regime shift, structural break

\section{Introduction}

The introduction and proliferation of various derivatives and exchange traded funds whose underlying assets are commodities have been spurring the increasing financialization of commodities, leading to more and more studies of this topic in recent years (i.e., Domanski and Heath, 2007; Inamura et al., 2011; Tang and Xiong, 2012). Because of this recent propagation, commodity prices may deviate from the fundamental value derived from supply and demand. Indeed, while Gorton and Rouwenhorst (2006) showed in the mid-2000s that commodity futures returns had a low correlation with stock returns, later research has presented evidence that lends support to the presence of a greater degree of correlation (Inamura et al., 2011; Tang and Xiong, 2012) (Note 1). In the same vein, although Erb and Harvey (2006) demonstrate that the correlations between various commodities are low, Inamura et al. (2011) and Tang and Xiong (2012) indicate that correlations among commodities returns have been climbing gradually since the mid-2000s, especially among commodities included in S\&P GSCI and DJ-UBSCI indexes. These facts suggest that diversification now offers fewer benefits to investors compared with a decade ago.

Given the mixed findings in publications since the turn of the century, this paper examines the long-run cointegrated relationship between gold and several key financial variables - the short-term interest rate, value of US dollar and stock index-over the past 20 years. Further, because the rising financialization of commodities might change the circumstances in the gold market through the changes of macro-financial environment and investors' behaviour, we allow the cointegrating relation to have a structural break that is endogenously determined by utilizing the algorithm developed by Gregory and Hansen (1996a). Previous studies in this area have applied Gregory and Hansen's (1996a) cointegration test to various economic and financial long-run relational modeling, such as to investigate the association between aggregate consumption and the wealth effect (Chen, 2006), comovements among international stock markets (Gupta and Guidi, 2012; Huang et al., 2000), interrelationships among stock prices and exchange rates (Yau and Nieh, 2006), the stability of money demand (Hacker and Hatemi-J, 2005; Rao and Kumar, 2011), the stability of import demand (Hamori and Matsubayashi, 2001), and the relationship among oil price, economic activity, US dollar and interest rates (Tamakoshi and Hamori, 2012).

The motivation of our study is strongly based on the findings presented by Hammoudeh et al. (2009) and Bhar and Hammoudeh (2011). Hammoudeh et al. (2009) explore the causal relationships between four commodities including gold and demonstrate that gold has a long-run negative impact on the exchange rate; in other words, an increase in the gold price leads to the depreciation of the US dollar. Bhar and Hammoudeh (2011) examine the dynamic interrelationships between four commodities including gold in a regime-switching framework and find that gold has no significant interrelationship with the studied financial variables, except for a positive effect on short-run interest 
rates in a high-volatility regime.

While the correlation between gold and stock returns has been increasing as the financialization of commodities has propagated, gold has begun to offer investors a tool with which to mitigate the risks of inflation and US dollar depreciation. Worthington and Pahlavani (2007), for example, find a cointegrating relationship between gold and CPI inflation in the US, providing evidence that gold serves as an effective inflation hedge (Note 2). Further, theoretically, the overshooting model predicts the existence of a negative relationship between commodities such as gold and interest rates (Frankel, 2006). Based on the structural vector autoregressive model, Akram (2009) also shows that commodity prices respond negatively to interest rate declines and that US dollar depreciation brings about higher commodity prices. Therefore, the close connection between gold and selected financial variables may influence the portfolio selection, risk management, and hedging strategies of investors.

Despite its interest to many international investors as an alternative instrument, however, academic research on gold is comparatively rare, and the interrelationship between gold as a financial asset and other financial markets remains understudied. The present paper bridges this gap in the body of knowledge by examining the cointegrating relationship among these variables for the first time. The presented analysis shows that there exists a cointegrating relation with regime shift between gold and the three financial variables, namely the short-term interest rate, value of US dollar, and stock index. Furthermore, taking into consideration the regime shift, we estimate the cointegrating vector and find that the coefficients of most of the financial variables have grown in terms of absolute value in later years. This finding suggests that gold has begun to be regarded as an important financial asset for making effective investments.

The rest of the article is organized as follows. We present the data used in Section II. Section III is devoted to our empirical results. Section IV concludes the paper.

\section{Data}

We construct the daily PM fixing of the London gold price in US dollars per troy ounce (GOLD). The data are derived from the London Bullion Market Association (Note 3). Following the approach taken by Bhar and Hammoudeh (2011), we choose the short-term interest rate, exchange rate, and stock market index as the financial variables to include in the system. We obtain the S\&P 500 index (SPX), the trade-weighted exchange index (US dollar against major currencies, TWEIM), and the three-month Treasury bill rate (TB3M) from the Federal Reserve Bank of St. Louis (Note 4, Note 5). In this study, the sample period runs from January 3, 1990, to May 31, 2013, and the number of observations is 5684. Table 1 summarizes the descriptive statistics of our data.

Table 1. Descriptive statistics

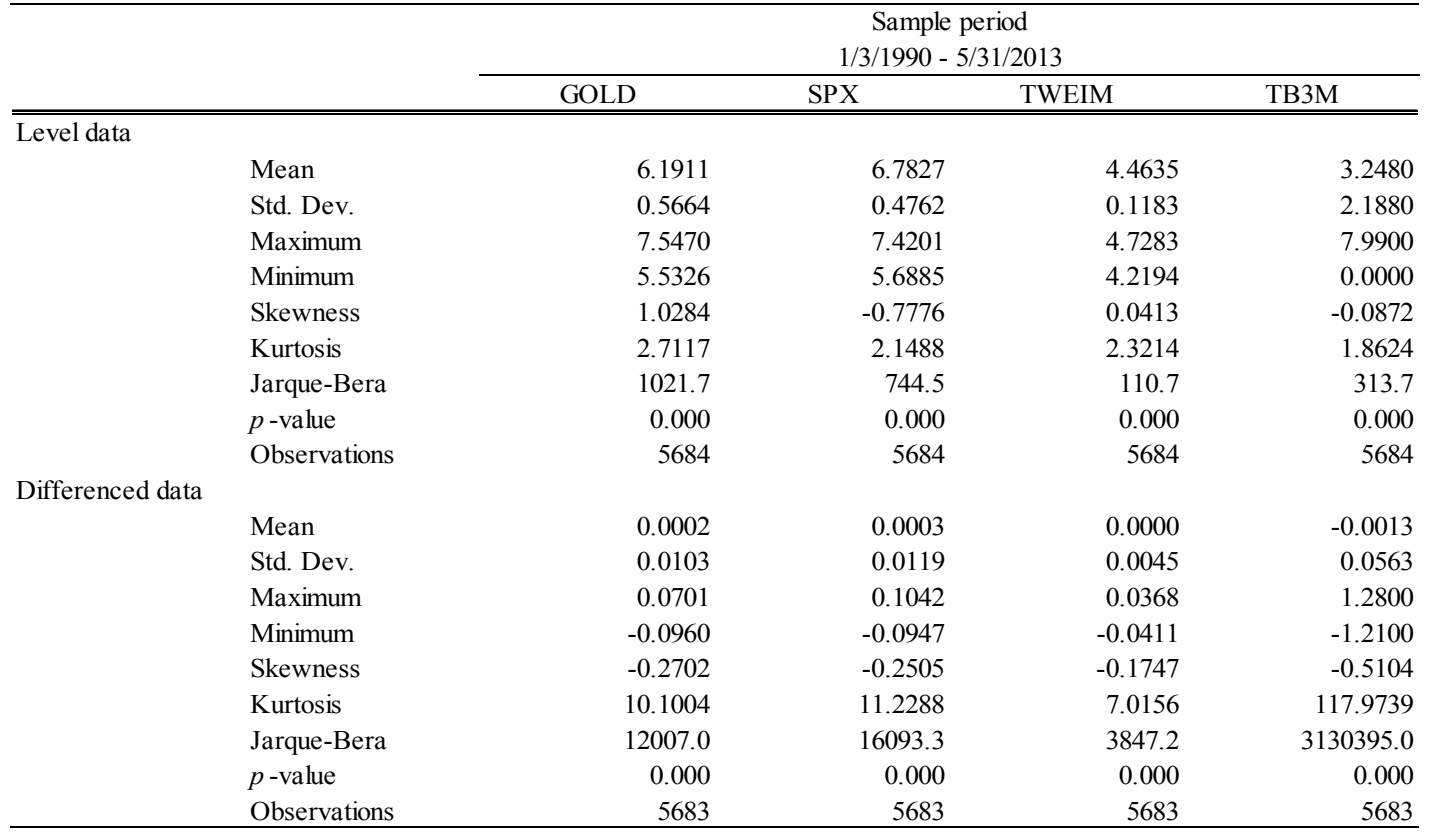

Notes: $p$-value corresponds to the Jarque-Bera statistic. The natural logarithm is taken for GOLD, SPX and TWEIM.

Figure 1 displays the time series plots of each variable used (all variables are scaled at natural logarithm except TB3M). Although the gold price decreased until around the end of 2001, subsequently it began to rise persistently. 
The short-term interest rate has fallen to near $0 \%$ at present, from approximately $8 \%$ at the beginning of 1990 . The US dollar has been depreciating against major currencies from its peak at the beginning of 2002. The SPX rapidly rose until collapse of the dot-com bubble, after which the US stock market experienced two troughs around the outbreak of the Iraq war in March 2003 and the collapse of Lehman Brothers in September 2008.
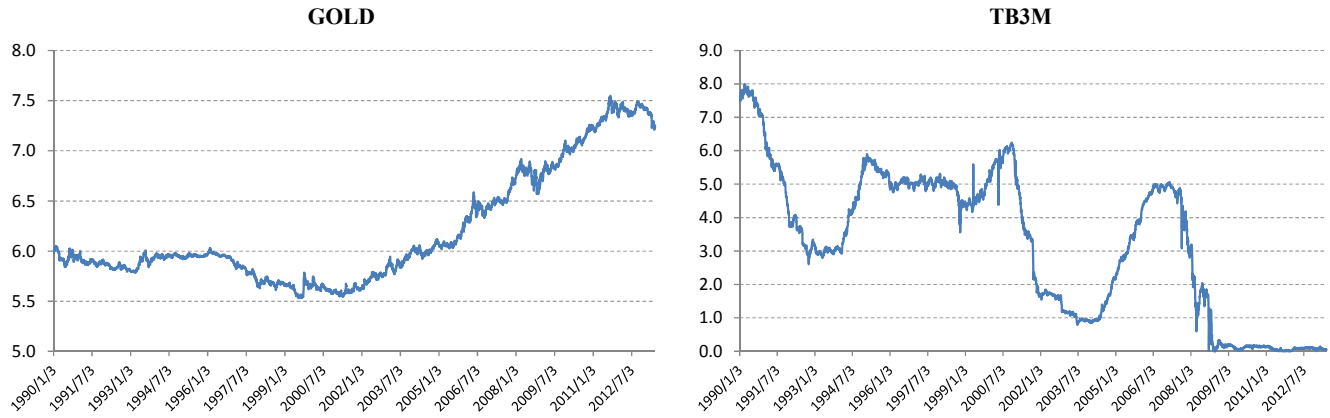

TWEIM

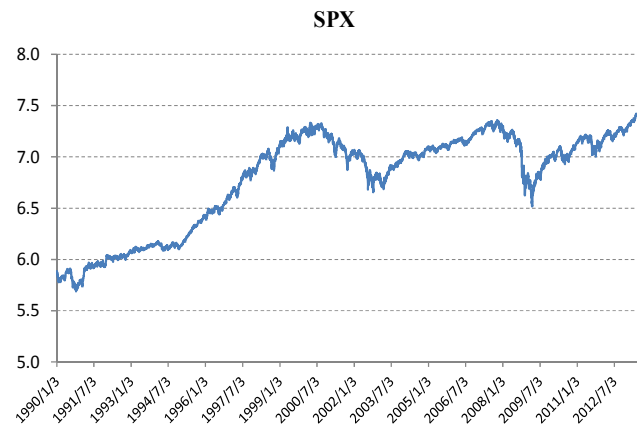

Figure 1. Time series plots of GOLD, TB3M, TWEIM, and SPX

Notes: This figure illustrates the time series plots of GOLD, SPX, TWEIM, and TB3M. The sample period runs from 1/3/1990 until 5/31/2013. GOLD, TWEIM, and SPX are log-scaled.

Table 2 reports the results of the unit root tests for both the Augmented Dickey-Fuller (ADF) and the PhillipsPerron (PP) tests. These tests provide qualitatively similar results; the null hypothesis of a unit root is not rejected in levels, but it is significantly rejected in differences. The only exception is TB3M, which rejects the null hypothesis in levels at $5 \%$ significance for the specification that excludes deterministic terms in levels. Despite this finding, we judge that the evidence for stationarity of TB3M is weak and treat TB3M as the $I(1)$ variable.

Table 2. Unit root test

\begin{tabular}{|c|c|c|c|c|c|}
\hline \multirow{2}{*}{$\begin{array}{c}\text { Testing } \\
\text { procedure } \\
\end{array}$} & & \multicolumn{4}{|c|}{$\begin{array}{c}\text { Sample period } \\
1 / 3 / 1990-5 / 31 / 2013\end{array}$} \\
\hline & & GOLD & SPX & TWEIM & TB3M \\
\hline \multirow[t]{8}{*}{ ADF test } & Level data & & & & \\
\hline & None & 1.876 & 1.950 & -0.583 & $-2.306 * *$ \\
\hline & Intercept & 0.840 & -1.589 & -1.337 & -1.555 \\
\hline & Intercept and trend & -1.520 & -1.642 & -1.767 & -1.754 \\
\hline & Differenced data & & & & \\
\hline & None & $-16.430 * * *$ & $-14.316 * * *$ & $-54.719 * * *$ & $-10.653 * * *$ \\
\hline & Intercept & $-16.532 * * *$ & $-14.469 * * *$ & $-54.718 * * *$ & $-14.962 * * *$ \\
\hline & Intercept and trend & $-16.700 * * *$ & $-14.490 * * *$ & $-54.715 * * *$ & $-14.970 * * *$ \\
\hline \multicolumn{6}{|l|}{ PP test } \\
\hline & Level data & & & & \\
\hline & None & 1.650 & 1.851 & -0.591 & $-2.383 * *$ \\
\hline & Intercept & 0.840 & -1.373 & -1.315 & -1.387 \\
\hline & Intercept and trend & -1.493 & -1.567 & -1.744 & -1.526 \\
\hline & Differenced data & & & & \\
\hline & None & $-16.430 * * *$ & $-81.618 * * *$ & $-76.312 * * *$ & $-73.751 * * *$ \\
\hline & Intercept & $-16.532 * * *$ & $-81.720 * * *$ & $-76.310 * * *$ & $-73.783 * * *$ \\
\hline & Intercept and trend & $-16.700 * * *$ & $-81.723 * * *$ & $-76.304 * * *$ & $-73.781 * * *$ \\
\hline
\end{tabular}

Notes: ${ }^{* *}$ and ${ }^{* * *}$ indicate statistical significance at the $5 \%$ and $1 \%$ levels, respectively. 


\section{Empirical Results}

\subsection{Johansen and Gregory-Hansen Cointegration Test}

Table 3 reports the results of the Johansen cointegration test (Johansen, 1988, Johansen and Juselius, 1990). Clearly, we cannot reject the null hypothesis of no cointegration in both the trace and the maximum eigenvalue tests. It is well known, however, that the power of the Johansen test falls drastically when a structural break exists in the data (Gregory and Hansen, 1996b). Based on the foregoing, we conduct the Gregory-Hansen cointegration test in order to take account of the possible existence of a structural break (Table 4). We estimate the most general model, namely regime shift model, as follows (Note 6):

$$
y_{1, t}=\mu_{1}+\mu_{2} \varphi_{t, \tau}+\alpha_{1}^{\prime} y_{2, t}+\alpha_{2}^{\prime} y_{2, t} \varphi_{t, \tau}+e_{t}
$$

where $y_{1}$ represents GOLD and $y_{2}$ represents the vector that includes TB3M, TWEIM and SPX. $\varphi_{t, \tau}$ is a dummy variable such that

$$
\varphi_{t, \tau}=0 \text { if } t \leq \tau \text { and } \varphi_{t, \tau}=1 \text { if } t>\tau .
$$

$\tau$ denotes a possible structural break date. The test statistics are given by:

$$
A D F^{*}=\inf f_{\tau \in T} A D F(\tau), \quad Z_{\alpha}^{*}=\inf f_{\tau \in T} Z_{\alpha}(\tau), \quad Z_{t}^{*}=\inf f_{\tau \in T} Z_{t}(\tau) .
$$

In contrast to the results presented in Table 3 , this test rejects the null hypothesis of no cointegration, that is, the three test statistics are statistically significant at the 5\% level, thereby supporting the existence of cointegration with a structural break or regime shift. This finding suggests that the failure of rejection in the Johansen test is attributable to the absence of a structural break. In addition, the break date is detected on December 8 or 13, 2005, which is the

\begin{tabular}{|c|c|c|c|}
\hline \multirow[b]{2}{*}{ Testing procedure } & \multicolumn{3}{|c|}{$\begin{array}{c}\text { Sample period } \\
1 / 3 / 1990-5 / 31 / 2013\end{array}$} \\
\hline & Null hypothesis & Test statistic & $5 \%$ critical value \\
\hline \multicolumn{4}{|l|}{ Trace test } \\
\hline & $r=0$ & 43.52 & 62.99 \\
\hline & $r=1$ & 22.53 & 42.44 \\
\hline & $r=2$ & 6.20 & 25.32 \\
\hline & $r=3$ & 1.64 & 12.25 \\
\hline \multicolumn{4}{|l|}{ Maximum eigenvalue test } \\
\hline & $r=0$ & 20.99 & 31.46 \\
\hline & $r=1$ & 16.34 & 25.54 \\
\hline & $r=2$ & 4.56 & 18.96 \\
\hline & $r=3$ & 1.64 & 12.25 \\
\hline
\end{tabular}
time when the gold price started to rise sharply and persistently.

Table 3. Johansen cointegration test

Notes: The order of lag length is 5 . The critical values are from Osterwald-Lenum (1992).

Table 4. Gregory-Hansen cointegration test

Model specification: Regime shift

$y_{1, t}=\mu_{1}+\mu_{2} \varphi_{t, \tau}+\alpha_{1}^{\prime} y_{2, t}+\alpha_{2}^{\prime} y_{2, t} \varphi_{t, \tau}+e_{t}$

\begin{tabular}{ccccc}
\hline & & \multicolumn{3}{c}{ Sample period } \\
Model & Testing & \multicolumn{3}{c}{ Dependent variable: GOLD } \\
\cline { 3 - 5 } specification & procedure & Test statistic & 5\% critical value & Break point \\
\cline { 3 - 5 } & & & -6.00 & $12 / 8 / 2005$ \\
\hline \hline Regime shift & & $-6.04^{* *}$ & -6.00 & $12 / 8 / 2005$ \\
& $A D F^{*}$ & $-6.29^{* *}$ & -68.94 & $12 / 13 / 2005$ \\
& $Z_{t}{ }^{*}$ & $-80.00^{* *}$ & & \\
& $Z_{\alpha}{ }^{*}$ & & &
\end{tabular}

Notes: The order of lag length is selected by using the AIC. ${ }^{* *}$ indicates statistical significance at the $5 \%$ level. The critical values are from Gregory and Hansen (1996a). 
Around this period, even though the Fed has repeatedly and gradually raised its federal funds rate over time, US monetary policy was rather loose because the federal funds rate remained below its natural level implied by the simple Taylor rule (Taylor, 2007a, 2007b). Furthermore, the global saving glut together with low interest rates in the US fueled the acceleration of house price rises (Bernanke, 2005, 2010; Taylor, 2007a, 2007b). As suggested by Inamura et al. (2011) and among others, the former may have also spurred money inflows into the gold market. Furthermore, as reviewed in the Introduction, this point of time concurs with when the correlation between commodities and stock returns increased (Inamura et al., 2011; Tang and Xiong, 2012). Consistent with the suggestion put forward by Inamura et al. (2011), therefore, we can infer that loose monetary policy at the US and at the global scale resulted in the estimation of the structural break date above.

\subsection{Dynamic OLS (DOLS) Estimation}

Table 5 shows the cointegrating vector estimated by the DOLS estimation proposed by Stock and Watson (1993) (Note 7). The regression model is as follows:

$$
y_{1, t}=\alpha+\beta^{\prime} y_{2, t}+\gamma \text { Dum }_{\alpha}+\delta^{\prime} \text { Dum }_{\beta} y_{2, t}+\sum_{i=-K}^{K} \theta_{i} \Delta y_{2, t-i}+u_{t},
$$

where the definition of $y_{1}$ and $y_{2}$ is the same as in equation (1) and Dum $m_{\alpha}$ and $D_{u} m_{\beta}$ are dummy variables that correspond to the break date detected above; thus, they take a value of 1 after December 13, 2005, and 0 otherwise (Note 8 ). $K$ represents the order of leads and lags for differenced regressors.

Panel A and Panel B in Table 5 report the estimation results of $K=5$ and $K=10$, respectively. In both cases, the results are very close to each other, confirming the robustness of the choice of the order of leads and lags, and all coefficients are highly significant.

Table 5 provides three insightful results. First, the dollar index is shown to be the most important variable for gold price movements in terms of the absolute estimation value. This finding concurs with those in the literature by showing that the depreciation of the dollar leads to a higher gold price. Second, there exists a structural break in both the intercept and the coefficients in all financial variables examined. In other words, a regime shift has occurred between gold and these financial variables (i.e., a shift of the cointegrating vector). The intercept dummy is negative and of a magnitude that almost offsets the positivity that occurred before the break. The interest rate dummy is also negative and it becomes even more negative after the break. Intuition suggests that the lowering of the interest rate caused by monetary expansion thus serves as a signal of economic recession. As a result, investors shift their assets to gold for refuge from the turmoil. Finally, the inflow of money supplied by central banks accelerates increases in asset prices. Although the dummy for the US dollar index is positive, the sum of the coefficients of the exchange rate is still negative. In addition, gold positively correlates with the SPX after the break, and the sum of the coefficients both before and after the break becomes positive. This finding implies that gold does not effectively act to reduce losses in the stock market downturn in the long run.

Overall, the presented analysis strongly suggests that the gold price has started to react more greatly to the behavior of the relevant financial variables. In other words, as suggested by Baur (2011) among others, gold has begun to be regarded as an important financial asset for making effective investments as the financialization of commodities has proliferated.

Table 5. DOLS estimation of the cointegrating vector

Regression model: $y_{1, t}=\alpha+\beta^{\prime} y_{2, t}+\gamma$ Dum $_{\alpha}+\delta^{\prime}$ Dum $_{\beta} y_{2, t}+\sum_{i=-K}^{K} \theta_{i} \Delta y_{2, t-i}+u_{t}$

\begin{tabular}{|c|c|c|c|c|c|c|c|c|c|}
\hline \multicolumn{2}{|l|}{ Panel A } & \multicolumn{3}{|c|}{$\begin{array}{c}\text { Sample period } \\
1 / 3 / 1990-5 / 31 / 2013\end{array}$} & \multicolumn{2}{|l|}{ Panel B } & \multicolumn{3}{|c|}{$\begin{array}{c}\text { Sample period } \\
1 / 3 / 1990-5 / 31 / 2013\end{array}$} \\
\hline \multirow{2}{*}{$\begin{array}{c}\text { Order of } \\
\text { leads and lags }\end{array}$} & \multirow[b]{2}{*}{ Prameter } & \multicolumn{3}{|c|}{ Dependent variable: GOLD } & \multirow{2}{*}{$\begin{array}{c}\text { Order of } \\
\text { leads and lags }\end{array}$} & \multirow[b]{2}{*}{ Prameter } & \multicolumn{3}{|c|}{ Dependent variable: GOLD } \\
\hline & & Estimate & S.E. & $p$-value & & & Estimate & S.E. & $p$-value \\
\hline$K=5$ & & & & & $K=10$ & & & & \\
\hline & $\alpha$ & $12.588 * * *$ & 0.206 & 0.000 & & $\alpha$ & $12.533 * * *$ & 0.215 & 0.000 \\
\hline & $\beta_{t b}$ & $-0.017 * * *$ & 0.002 & 0.000 & & $\beta_{t b}$ & $-0.017 * * *$ & 0.002 & 0.000 \\
\hline & $\beta_{e x}$ & $-1.416 * * *$ & 0.055 & 0.000 & & $\beta_{e x}$ & $-1.402 * * *$ & 0.057 & 0.000 \\
\hline & $\beta_{s p}$ & $-0.040 * * *$ & 0.012 & 0.001 & & $\beta_{s p}$ & $-0.042 * * *$ & 0.012 & 0.001 \\
\hline & $\gamma$ & $-11.331 * * *$ & 1.831 & 0.000 & & $\gamma$ & $-11.528 * * *$ & 1.841 & 0.000 \\
\hline & $\delta_{t b}$ & $-0.174 * * *$ & 0.009 & 0.000 & & $\delta_{t b}$ & $-0.175 * * *$ & 0.009 & 0.000 \\
\hline & $\delta_{e x}$ & $1.155 * * *$ & 0.319 & 0.000 & & $\delta_{e x}$ & $1.156 * * *$ & 0.325 & 0.000 \\
\hline & $\delta_{s p}$ & $1.037 * * *$ & 0.086 & 0.000 & & $\delta_{s p}$ & $1.065 * * *$ & 0.083 & 0.000 \\
\hline & $\bar{R}^{2}$ & & & 0.972 & & $\bar{R}^{2}$ & & & 0.973 \\
\hline
\end{tabular}

Notes: ${ }^{*},{ }^{* *}$, and ${ }^{* * *}$ indicate statistical significance at the $10 \%, 5 \%$, and $1 \%$ levels, respectively. For the DOLS estimation, the standard errors are adjusted by using the Newey-West (1987) method. 


\section{Conclusion}

In this paper, we presented and used the Gregory-Hansen cointegration test in order to examine the long-run relationship between gold and three financial variables, namely the short-term interest rate, US dollar, and stock market. We demonstrated that there exists a cointegrating relationship with regime shift among these variables based on the analysis of daily data from January 1990 to May 2013. In addition, our regression analysis, which takes into account a structural break, implies that the coefficients between most of the financial variables and the gold price have increased in absolute value in later years. As the financialization of commodities advances, this finding suggests that gold has begun to be regarded as an important financial asset for making effective investments. Nonetheless, one consequence is that gold may lose any benefits from diversification following the increase in correlations among different asset classes.

The developments of new financial product and technology facilitate investing gold. Thereby, assessing the properties of gold as a financial instrument is intriguing issue in terms of portfolio selection and asset allocation. It is probable that the relationship between gold and financial variables will change. Particularly, in the recent financial crisis, gold has attracted a great deal of investors' attention as a safety asset. Investigating how gold responds to tightening of financial condition is left for future research.

\section{Acknowledgements}

We are very grateful to an anonymous referee and the editor for valuable comments and suggestions.

\section{References}

Akram, Q.F. (2009). Commodity prices, interest rates and the dollar. Energy Economics, 31, 838-851. http://dx.doi.org/10.1016/j.eneco.2009.05.016

Baur, D.G. (2011). Explanatory mining for gold: Contrasting evidence from simple and multiple regressions. Resources Policy, 36, 265-275. http://dx.doi.org/10.1016/j.resourpol.2011.03.003

Bernanke, B.S. (2005). The Global Saving Glut and the U.S. Current Account Deficit, Remarks by Governor Ben S. Bernanke at the Sandridge Lecture, Virginia Association of Economists, Richmond, Virginia. Retrieved from http://www.federalreserve.gov/boarddocs/speeches/2005/200503102/

Bernanke, B.S. (2010). Monetary policy and the housing bubble. Board of Governors of the Federal Reserve System at the Annual Meeting of the American Economic Association, Atlanta, Georgia. Retrieved from http://www.federalreserve.gov/newsevents/speech/bernanke20100103a.pdf

Bhar, R., \& Hammoudeh, S. (2011). Commodities and financial variables: Analyzing relationships in a changing regime environment. International Review of Economics and Finance, 20, 469-484. http://dx.doi.org/10.1016/j.iref.2010.07.011

Chan, K.F., Treepongkaruna, S., Brooks, R., \& Gray, S. (2011). Asset market linkages: Evidence from financial, commodity and real estate assets. Journal of Banking \& Finance, 35, 1415-1426. http://dx.doi.org/10.1016/j.jbankfin.2010.10.022

Chen, J. (2006). Re-evaluating the association between housing wealth and aggregate consumption: New evidence from Sweden. Journal of Housing Economics, 15, 321-348. http://dx.doi.org/10.1016/j.jhe.2006.10.004

Chong, J., \& Miffre, J. (2010). Conditional correlation and volatility in commodity futures and traditional asset markets. Journal of Alternative Investments, 12, 61-75. http://dx.doi.org/10.3905/jai.2010.12.3.061

Domanski, D., \& Heath, A. (2007, March). Financial investors and commodity markets. BIS Quarterly Review, 53-67. Retrieved from http://bis.hasbeenforeclosed.com/publ/qtrpdf/r_qt0703g.pdf

Erb, C.B., \& Harvey, C.R. (2006). The strategic and tactical value of commodity futures. Financial Analysts Journal, 62, 69-97. http://dx.doi.org/10.2469/faj.v62.n2.4084

Frankel, J.A. (2006). The effect of monetary policy on real commodity prices. NBER book, University of Chicago Press. Retrieved from http://www.nber.org/chapters/c5374

Gorton, G., \& Rouwenhorst, K.G. (2006). Facts and fantasies about commodity futures. Financial Analysts Journal, 62, 47-68. http://dx.doi.org/10.2469/faj.v62.n2.4083

Gregory, A.W., \& Hansen, B.E. (1996a). Residual-based tests for cointegration in models with regime shifts. Journal of Econometrics, 70, 99-126. http://dx.doi.org/10.1016/0304-4076(69)41685-7 
Gregory, A.W., \& Hansen, B.E. (1996b). Tests for cointegration in models with regime and trend shifts. Oxford Bulletin of Economics and Statistics, 58, 555-560. http://dx.doi.org/10.1111/j.1468-0084.1996.mp58003008.x

Gupta, R., \& Guidi, F. (2012). Cointegration relationship and time varying co-movements among Indian and Asian developed stock markets. International Review of Financial Analysis, 21, 10-22. http://dx.doi.org/10.1016/j.irfa.2011.09.001

Hacker, R.S., \& Hatemi-J, A. (2005). The effect of regime shifts on the long-run relationships for Swedish money demand. Applied Economics, 37, 1731-1736. http://dx.doi.org/10.1080/00036840500215444

Hammoudeh, S., Sari, R., \& Ewing, B.T. (2009). Relationships among strategic commodities and with financial variables: a new look. Contemporary Economic Policy, 27, 251-264. http://dx.doi.org/10.1111/j.1465-7287.2008.00126.x

Hamori, S., \& Matsubayashi, Y. (2001). An empirical analysis on the stability of Japan's aggregate import demand function. Japan and the World Economy, 13, 135-144. http://dx.doi.org/10.1016/s0922-1425(00)00063-3

Huang, B.N., Yang, C.W., \& Hu, J.W.S. (2000). Causality and cointegration of stock markets among the United States, Japan and the South China Growth Triangle. International Review of Financial Analysis, 9, $281-297$. http://dx.doi.org/10.1016/s1057-5219(00)00031-4

Inamura, Y., Kimata, T., Kimura, T., \& Muto, T. (2011, March). Recent surge in global commodity prices -Impact of financialization of commodities and globally accommodative monetary conditions. Bank of Japan Review. Retrieved from http://www.boj.or.jp/en/research/wps_rev/rev_2011/data/rev11e02.pdf

Johansen, S. (1988). Statistical analysis of cointegration vectors. Journal of Economic Dynamics and Control, 12, 231-254. http://dx.doi.org/10.1016/0165-1889(88)90041-3

Johansen, S., \& Juselius, K. (1990). Maximum likelihood estimation and inference on cointegration with application to the demand for money. Oxford Bulletin of Economics and Statistics, 52, 169-209. http://dx.doi.org/10.1111/j.1468-0084.1990.mp52002003.x

Mahdavi, S., \& Zhou, S. (1997). Gold and commodity prices as leading indicators of inflation: tests of long-run relationship and predictive performance. Journal of Economics and Business, 49, 475-489. http://dx.doi.org/10.1016/s0148-6195(97)00034-9

Miyazaki, T., Toyoshima, Y., \& Hamori, S. (2012). Exploring the dynamic interdependence between gold and other financial markets. Economics Bulletin, 32, 37-50.

Miyazaki, T., \& Hamori, S. (2013). Testing for causality between the gold return and stock market performance: evidence for 'gold investment in case of emergency'. Applied Financial Economics, 23, 27-40. http://dx.doi.org/10.1080/09603107.2012.699184

Montalvo, J.G. (1995). Comparing cointegrating regression estimators: Some additional Monte Carlo results. Economics Letters, 48, 229-234. http://dx.doi.org/10.1016/0165-1765(94)00632-c

Newey, W.K., \& West, K.D. (1987). A simple, positive semi-definite, heteroskedasticity and autocorrelation consistent covariance matrix. Econometrica, 55, 703-708. http://dx.doi.org/10.2307/1913610

Osterwald-Lenum, M. (1992). A note with quintiles of the asymptotic distribution of the maximum likelihood cointegration rank test statistics. Oxford Bulletin of Economics and Statistics, 54, 461-472. http://dx.doi.org/10.1111/j.1468-0084.1992.tb00013.x

Park, J.Y. (1992). Canonical cointegrating regressions. Econometrica, 60, $119-143$. http://dx.doi.org/10.2307/2951679

Phillips, P.C.B., \& Hansen, B.E. (1990). Statistical inference in instrumental variables regression with $I(1)$ processes. Review of Economic Studies, 57, 99-125. http://dx.doi.org/10.2307/2297545

Rao, B.B., \& Kumar, S. (2011). Is the US demand for money unstable? Applied Financial Economics, $21,1263-1272$. http://dx.doi.org/10.1080/09603107.2011.568395

Sari, R., Hammoudeh, S., \& Soytas, U. (2010). Dynamics of oil price, precious metal prices, and exchange rate. Energy Economics, 32, 351-362. http://dx.doi.org/10.1016/j.eneco.2009.08.010

Stock, J.M., \& Watson, M.W. (1993). A simple estimator of cointegrating vectors in higher order integrated systems. Econometrica, 61, 783-820. http://dx.doi.org/10.2307/2951763 
Stock, J.M., \& Watson, M.W. (2011). Introduction to Econometrics (3rd international ed.). Pearson Education.

Tamakoshi, G., \& Hamori, S. (2012). Real oil prices, real economic activity, real interest rates, and the US dollar: A cointegration analysis with structural breaks. Journal of Reviews on Global Economics, 1, 41-46. http://dx.doi.org/10.6000/1929-7092.2012.01.4

Tang, K., \& Xiong, W. (2012). Index investment and the financialization of commodities. Financial Analysts Journal, 68, 54-74. http://dx.doi.org/10.2469/faj.v68.n6.5

Taylor, J.B. (2007a, October). The explanatory power of monetary policy rules: Simple principles have big impacts. Business Economics, 8-15. Retrieved from http://web.stanford.edu/ johntayl/Onlinepaperscombinedbyyear/2007/2007/The_Explanatory_Power_of_Monet ary_Policy_Rules.pdf

Taylor, J.B. (2007b). Housing and monetary policy, NBER Working Paper Series, No. 13682, Retrieved from http://www.nber.org/papers/w13682.pdf?new_window=1

Worthington, A., \& Pahlavani, M. (2007). Gold investment as an inflationary hedge: cointegration evidence with allowance for endogenous structural breaks. Applied Financial Economics Letters, 3, 259-262. http://dx.doi.org/10.1080/17446540601118301

Yau, H.Y., \& Nieh, C.C. (2006). Interrelationships among stock prices of Taiwan and Japan and NTD/Yen exchange rate. Journal of Asian Economics, 17, 535-552. http://dx.doi.org/10.1016/j.asieco.2006.04.006

\section{Notes}

Note 1. Chong and Miffre (2010) examine the dynamic conditional correlation (DCC) between commodities and traditional assets. Miyazaki et al. (2012) use the asymmetric DCC model in order to explore gold and other financial markets. Miyazaki and Hamori (2013) perform statistical tests for causality between gold and stock for both returns and volatilities. See also Chan et al. (2011) and Sari et al. (2010) for linkages between commodities including gold and other asset markets.

Note 2. For the relation between gold and inflation, see also Mahdavi and Zhou (1997).

Note 3. Refer to http://www.lbma.org.uk/pages/index.cfm.

Note 4. Bhar and Hammoudeh (2011) use the Morgan Stanley Capital International index as their stock market index rather than the SPX. Thus, the presented analysis is mainly based on the perspectives of US investors.

Note 5. Refer to http://www.stlouisfed.org/ for more information on each variable.

Note 6. We also estimate the level shift and level shift with trend models. However, we cannot reject the null hypothesis of no cointegration for these specifications.

Note 7. See also Stock and Watson (2011) for more details on the estimation of DOLS. We also applied two alternative estimation methods, namely fully modified OLS and canonical cointegrating regression (Phillips and Hansen, 1990; Park, 1992). These methods produced somewhat different results compared with DOLS. Following Montalvo (1995), we thus adopt and report only the reliable result achieved by using DOLS, but all results are available from the authors upon request.

Note 8. We assume December 13, 2005 to be a structural break date because the test statistic that corresponds to this date, $Z_{\alpha}^{*}$, is the most statistically significant. 